\title{
Microbiological Quality of Fresh, Cold, and Frozen Beef at the Bogor Traditional Markets and Supermarkets
}

\author{
Dian Sundari ${ }^{1, *}$, Fitrah Ernawati ${ }^{1}$, Kambang Sariadji ${ }^{1}$, Efriwati ${ }^{1}$, Nelis Imanningsih ${ }^{1}$, \\ Nunung Nurjanah ${ }^{1}$, Ema Sahara ${ }^{1}$, Mutiara Prihatini ${ }^{1}$, Aya Yuriestia ${ }^{1}$ \\ ${ }^{1}$ Centre for Research and Development of Biomedical and Basic Health Technology, National Institute of Health \\ Research and Development, Ministry of Health, Jakarta, Indonesia \\ "Corresponding author.Email: diansun0706@gmail.com
}

\begin{abstract}
Beef is one of the food sources of animal protein which provides fulfilment of community nutrition, because it is easily damaged, preservative methods are needed so that the quality of fresh meat remains good. A crosssectional study identified the quality of the microbiological content in fresh, cold and frozen beef from traditional markets and supermarkets in Bogor. The bacteria examined were Eschercia coli, Staphylococcus aureus, Camphylobacter sp. and Salmonella sp. Bacterial analysis using TPC (Total of Plate Count) method. The results showed that for beef from traditional markets, Escherichia coli bacteria found in fresh beef ranged from $0-10 \times 10^{1} \mathrm{cfu} / \mathrm{g}$ and in frozen beef ranged from $0-4 \times 10^{1} \mathrm{cfu} / \mathrm{g}$. For beef from the supermarket, E. coli bacteria found in cold beef ranged from $0-1.3 \times 10^{1} \mathrm{cfu} / \mathrm{g}$, while in frozen meat it was not found (negative). Staphylococcus aureus is found in frozen beef ranging from $0-16.7 \times 10^{1} \mathrm{cfu} / \mathrm{g}$ from traditional markets while in fresh meat is not found. For meat from supermarket, both cold and frozen meat, $S$. aureus is not found (negative). Beef from traditional markets both fresh and frozen meat, Camphylobacter sp. not found (negative). Likewise with cold and frozen meat from the supermarket Camphylobacter sp. not found either (negative). For Salmonella sp. bacteria, beef from traditional markets with fresh and frozen conditions and from supermarkets in cold and frozen beef conditions, Salmonella sp. not found (negative). The conclusion was found Escherichia coli bacteria in beef from traditional markets and supermarkets. Staphylococcus aureus was also found in beef from traditional markets. The number of both bacteria exceeds the specified limit. Salmonella sp was not found in accordance with the Indonesian National Standard (SNI), so it can be said that beef sold in traditional markets and supermarkets in Bogor is suitable for consumption by cooking perfectly.

Keywords: microbiology, fresh meat, cold, frozen, traditional markets, supermarkets
\end{abstract}

\section{INTRODUCTION}

Beef is one of animal protein which provides the fulfilment of high nutrient for people. In the last five years the availability of beef in the country has tended to increase, but the demand for beef has also increased, so it can be said that the average growth of production remain stagnant. The susenas data states the average of beef consumption for Indonesian people in 2017 was expected around $3 \mathrm{~kg} / \mathrm{capita} / \mathrm{year}$, it meant that the National beef demand in 2017 had reached 784.000 tons. Meanwhile, the beef production in 2017 was expected to be around 532.000 tons. In order to suffice the beef demand, would be needed the addition of beef by importing [1].
Beef is easily damaged, hence it needs a preserve way so that the beef quality is still good until it is consumed. One of the way to store and preserve it is by keeping it under the solidification temperature. The beef storage in a solidification temperature is enough to maintain the beef quality either in nutrition or microbiological aspect, but the quality degree is really affected by the solidification temperature, the storage duration, and how it was being packaged $[2,3]$.

The damage and rotten beef was caused by the microorganism activity. Lawrie (2003) stated that meat is an ideal media for microorganism breeding (either 
destroyes microorganism or rotter). It was caused by the percentage of water for the beef was really high $68-75 \%$, and had $\mathrm{pH}$ 5.3-6.5 which was profitable for the growth of a microorganism. Previous research states there was no difference in the quality of macro nutrients in fresh, cold or frozen beef from traditional markets and supermarkets, except for the protein content. Protein in cold meat is higher than frozen meat [4].

The harmful microbe contamination for the beef since it was livestock still alive was a microbe that still adhered on the ski surface and rumen, although it was already slaughtered. The contamination in a slaughter house was from the floor, knives, skin, insentines, water, and equipment used for carcass preparation. Microbial contamination of the carcass occurs since slaughtered, the process of preparing carcasses, meat on the market until the meat will be consumed, as well as from its own workers [2,5].

Although there is no difference in the quality of macro nutrition in fresh, cold or frozen beef, the difference in the quality of meat from microbial contamination has not been done. Therefore research has been carried out on microbial contamination in fresh, cold and frozen meat circulating in the market. The research aims to assess the microbiological quality of fresh, cold and frozen beef that circulates in supermarkets and traditional markets. While the benefits of this research are information for the community in choosing the best beef for consumption.

\section{METHOD}

\section{Research Setting}

Beef sampling has been done in traditional markets and supermarkets in the city of Bogor. Sample preparation and testing were conducted at Bacteriology, The National Laboratory, National Institute of Health Research and Development, Jakarta, in August - September 2016.

\section{Research Design}

The research design used was cross-sectional.

\section{Research Variability}

Independent Variability : Kinds of the Market, Beef Condition (fresh, cold and frozen)

Dependent Variability : TPC Escherichia .coli, Salmonella sp., Staphylococcus aureus and Campylobacter.

\section{Sample Collection}

Fresh beef was taken from traditional market, cold beef was taken from supermarket, and frozen beef was taken from traditional market and supermarket. Sample collection was done for 3 replication. Samples from traditional markets was bought from 3 traders, samples from supermarkets was bought from 3 different supermarkets. Beef is brought using a cool box with gel pack inside. Moreover, interviews session was conducted with beef traders and observing the conditions of the meat market.

\section{Bacteriology Examination Sample Preparation}

The sample preparation for bacterial counting was done by: weight 5 grams of the sample and add it to the blender, add 45 mL PBS (Phosphate Buffer Saline). Blend for 2 minutes. The result of the blender is dilution 101. Made dilution using a pipette 102, 103, 104 and soon. The results of homogenization and analysis was carried out at Bacteriology, The National Laboratory, National Institute of Health Research and Development.

\section{Bacteria Analysis}

Bacteria analysis used TPC (Total Plate Count) method. The TPC principle was meant to show the amount of microbes present in a product by counting the bacterial colonies that was being grown on agar media. Bacterial cultures examined Escherichia coli, Staphylococcus aureus, Champhylobacter sp. and Salmonella sp.

\section{Data Analysis}

The amount of beef microbes in fresh, cold and frozen conditions was calculated on average and was being compared by Indonesian National Standard (SNI): 7388:2009 (2009) about the maximum limit of microbial contamination in food.

\section{Ethical Clearance}

The researchers did not ask for the Ethical Clearance Commition, National Institute of Health Research and Development as this research was not subjected to human or trial animals.

\section{RESULTS AND DISCUSSION}

\section{Beef sources}

Beef that was for sale in Bogor was from local and import cows. The local cow was slaughtered in a slaughter house in Bogor and Jakarta. Frozen beef from supermarket was imported frozen beef. The supplier in traditional market bought the beef in a slaughter house at 11 P.M. until 2 A.M., and then sold it until the next afternoon. The beef that was not sold yet would be kept in a freezer and the supplier would sell it again for the next day (it was called frozen beef).

\section{Microbiological Quality}

The results of the study of the average number of bacteria that have been examined can be seen in Table 1 . 
Table 1. Average amount of Escherichia coli, Staphylococcus aureus, Camphylobacter sp. and Salmonella sp. in beef from traditional markets and supermarkets

\begin{tabular}{|c|c|c|c|c|}
\hline \multirow{2}{*}{$\begin{array}{c}\text { Types of } \\
\text { microbial } \\
\text { contamination }\end{array}$} & \multirow{2}{*}{$\begin{array}{l}\text { Beef } \\
\text { condition }\end{array}$} & \multicolumn{2}{|c|}{$\begin{array}{l}\text { Average microbial contamination } \\
(\mathrm{cfu} / \mathrm{g})\end{array}$} & \multirow{2}{*}{$\begin{array}{l}\text { Reference } \\
\text { value } \\
\text { SNI } 7388 \\
2009 \text { [8] }\end{array}$} \\
\hline & & $\begin{array}{l}\text { Traditional } \\
\text { Markets }\end{array}$ & Supermarkets & \\
\hline \multirow[t]{3}{*}{ Escherichia coli } & Fresh & $10 \times 10^{1}$ & - & \multirow{3}{*}{$1 \times 10^{1} / \mathrm{gr}$} \\
\hline & Cold & & $1.3 \times 10^{1}$ & \\
\hline & Frozen & $4 \times 10^{1}$ & Negative & \\
\hline \multirow{3}{*}{$\begin{array}{l}\text { Staphylococcus } \\
\text { aureus }\end{array}$} & Fresh & Negative & - & \multirow{3}{*}{$1 \times 10^{2} / g r$} \\
\hline & Cold & - & Negative & \\
\hline & Frozen & $16.7 \times 10^{1}$ & Negative & \\
\hline \multirow{3}{*}{$\begin{array}{c}\text { Champhylobacter } \\
\text { Sp. }\end{array}$} & Fresh & Negative & - & \multirow{3}{*}{ Negative/25 gr } \\
\hline & cold & - & Negative & \\
\hline & Frozen & Negative & Negative & \\
\hline \multirow{3}{*}{ Salmonella sp. } & Fresh & Negative & & \multirow{3}{*}{ Negative/25 gr } \\
\hline & Cold & - & Negative & \\
\hline & Frozen & Negative & Negative & \\
\hline
\end{tabular}

\section{The Amount of Eschericia coli}

The result of this study showed that the average of E. coli in fresh beef from traditional markes was ranged from 0-10 x $10^{1} \mathrm{cfu} / \mathrm{g}$, while frozen beef ranged from $0-4 \times 10^{1}$.cfu/g. The amount was above the required limit. The amount of $\mathrm{E}$. coli in cold beef from supermarkets ranges from $0-1.3 \mathrm{x}$ $10^{1} \mathrm{cfu} / \mathrm{g}$, the amount is above the required limit, while frozen meat is not found E. coli bacteria as required..

\section{The Amount of Staphylococcus aureus}

The result of this study showed that the average of Staphylococcus aureus in fresh beef from traditional markets was not found (negative), while the frozen beef was around $0-16.7 \times 10^{1} \mathrm{cfu} / \mathrm{g}$. The amount is above the required limit. The amount of $\mathrm{S}$. aureus in cold and frozen beef from supermarkets is not found (negative), this is as required.

\section{The Amount of Campylobacter sp.}

The result of this study showed that the average of Campylobacter sp. showed that in all beef conditions (fresh, cold and frozen) both from traditional markets and supermarkets, there was no bacterial Campylobacter sp.(negative) and this is as required.

\section{The Amount of Salmonella sp.}

The result of the study showed that the amount of Salmonella sp. in fresh, cold and frozen beef from traditional market and supermarket were negative, this is as required.

\section{Discussion}

The quality of carcasses and beef was influenced by environmental conditions, facilities and infrastructure of Slaughterhouses, the condition of livestock before slaughtering, the process of slaughtering and handling carcasses, the process of transporting meat, and the process of selling to the processing. The quality of frozen beef would be affected by its condition before it was being frozen. The devitiation that was done before freezing process could not be fixed by the way it was being frozen. As the foundation of frozen beef would not fix the quality but in would maintain the quality as before. So, if a devitiation happened before the freezing process, the impact would still happen.

Escherichia coli is a normal flora in a digestive tract of livestock and human. Pathogenic Escherichia coli strains could cause an infection and foodborn disease such as O157:H7 thay produced shiga toxin [9]. E. coli is a gramnegative microorganism, grows optimally at $37^{\circ} \mathrm{C}$ temperature, but could grow at a temperature range of 15$45^{\circ} \mathrm{C}$ [10]. In this study, still found E. coli contamination in fresh and frozen beef from traditional markets is above the required limit by SNI 3932: 2008 and SNI: 7388: 20093. The same research reported by B. Koentoro et al. (2013), E. Coli bacteria was still found in fresh beef from slaughterhouses in Pekanbaru. These conditions could be remedied by perfect cooking. As what Endang (2009) already stated that E. coli is a normal microbe in the digestive tract and it was pathogenlly, but with a perfect cooking, E. coli could be destroyed as the microbe was sensitive towards heat at $60^{\circ} \mathrm{C}$ for 30 minutes.

Another study in Egypt also stated that the percentage of E. coli in frozen beef was much higher than fresh beef. The faster it was being frozen, the percentage of E. coli would increase. The contamination from E. coli bacterial in beef was closely related to how low the sanitation problem was in the beef process handling. The process of preparing the sale of beef in traditional markets was not notice the sanitary and hygiene aspect as the prepared beef for sale was not being closed and stored in a cold temperature and the effects of storage temperature would affect to the bacterial breeding fastly. Likewise in frozen meat, frozen beef is usually left over from unsold, then sold later the next day [13].

Staphylococcus aureus is one of normal micro flora in poultry and turned out that good process was not fully guarantee that it could prevent the contamination by S. Aureus. The food stuff that was being prepared by using hands, such as raw vegetable preparation for salad, was potentially contaminated by S. Aureus. Another kinds of food that often contaminated by S. Aureus were beef, meat products, chicken, eggs, salads (egg, tuna, chicken, potatoes, and macaroni), bakery products, pastries, pies, sandwiches, milk, and milk products [14].

In this study still found contamination of Staphylococcus aureus bacterial in frozen beef from traditional markets above the specified limit $\left(16.7 \times 10^{1}\right)$. This could happened to lack of hygiene of the trade, so that the sanitation of the equipment and suitable storage causes no growth of Staphylococcus aureus. As Rombaut (2005) already stated that good environment from animals, humans, and equipment used, should be in a clean condition. The unsuitable equipment and storage could cause S. aureus growth. Stapylococcus aureus produces several enterotoxins. Most of these enterotoxins could survive at boiling temperatures in food for up to 30 minutes. Warming over this time will lose $60-70 \%$ of its activity [17]. 
Camphylobacter sp. is a microorganism that was being connected with a number of disease that occur in animals. But, in the evolution was derivate that bacteria was zoonosis, it could cause diarrhea and intestinal infection for human. Camphylobacter jejuni is commonly found in the digestive tract of animals. It was a pathogenic bacterial for human that could cause enteritis and sometimes systemic invasion, especially for baby 18 . In this study, the bacteria was not found in fresh and frozen beef in traditional market and supermarket. It could happen as the beef was from healthy cows.

Salmonella sp. is a gram-negative microorganism, in form of a stick, did not make spore, and one of Enterobacteriaceae class. Salmonella microorganism caused salmonellosis sucs as typhus or paratyhoid. The contamination and diffusion of Salmonella infection could happen from animals and human's feses [19]. In this study, Salmonella did not found in fresh and frozen beef from traditional markets, as well as in cold and frozen beef from supermarket. As SNI regulation (SNI: 3239:2008) to all kinds of beef and its processed product was not contain Salmonella sp. Based on that standard, fresh, cold and frozen beef in several traditional market and supermarket in the city of Bogor already fulfilled the determinated standard, because the result of this study found out beef that already examined was not contain Salmonella sp. This results showed that the quality of beef sold in several traditional markets and supermarket in Bogor was quite good. According to Hariyadi (2005), Salmonella is a bacteria indicator for food safety, as all Salmonella serotypes always known as something that was pathogenic so that this bacteria was dangerous for human's health. Besides food stuff, Salmonella also requires conditions such as temperature and $\mathrm{pH}$.

The source of the contamination could be influenced by several reasons, not only influenced by the hygiene of the location anf personal. In Self Life of Australian Read Meat Second Edition (2016) stated that the source of beef contamination usually starts from animals in the farmed, in the slaughterhouses when livestock was slaughter, packaging process, until it was ready to be consumption. When the researcher did the observation, the beef was closely related to how low sanitation problems was in its handle process. The beef preparation process in traditional market was not pay much attention to sanitation and hygiene aspect as the prepared beef for sale was not being closed and stored a cold temperature and the effects of storage temperature would affect to the bacterial breeding fastly.

\section{CONCLUSION}

Escherichia coli was found in beef from tradisional markets and supermarkets and Staphylococcus aureus in beef from traditional markets with amounts exceeded the permitted limit. Either Camphylobancre sp or Salmonella sp. were not found, it was suitable with Indonesian National Standard (SNI). It could be said that beef sold in tradisional markets and supermarkets in Bogor was suitable for consumption if accompanied by perfect cooking.

\section{Suggestion}

1. Freezing the beef before selling it could maintain the nutrition quality and its microbiology as long as the temperature is controlled under recommended solidification temperature $(<-200 C)$.

2. A socialization is needed about how to handle the beef hygienically from slaughterhouse to the supplier at the market, especially traditional markets.

\section{ACKNOWLEDGMENT}

Our sincere thanks go to the Head of the National Institute of Health Research and Development, the Head of Centre for Research and Development of Biomedical and Basic Health Technology who has provided financial support and facilities to conduct this research. Thanks also were for to fellow researchers and research assistants from the Bacteriology Laboratory, National Laboratory and Pharmacy Laboratory, National Laboratory of the National Institute of Health Research and Development and all parties involved in this study.

\section{REFERENCES}

[1] Anonim, 2018. Distribusi Perdagangan Komoditas Daging Sapi Indonesia Tahun 2018. Badan Pusat Statistik Indonesia.

[2] Anonim, 2016. Self Life of Australian Read Meat Second Edition. Meat and Life Stoke Australia.

[3] Lawrie, R.A. 2003. Ilmu Daging. Edisi 5 Penerjemah Aminuddin Parakkasi. Penerbit Universitas Indonesia Jakarta.

[4] Fitra dkk. 2018. Kualitas Dging Beku, Dingin dan Segar : pH dan Gizi. Jurnal Penelitian Gizi dan Makanan, Vol. 41. No. 1.

[5] Arifin,M., B. Dwiloka dan D.E. Patriani. 2008. Penurunan Kualitas Daging Sapi yang terjadi selama Proses Pemotongan dan Distribusi di Kota Semarang. Prosiding Seminar Nasional Teknologi Peternakan dan Veteriner. Bogor, 11-12 Nopember 2008, p: 99-104.

[6] Standar Nasional Indonesia. 2008. Metode Pengujian Cemaran Mikroba dalam Daging, Telor dan Susu, Serta Hasil Olahannya. SNI 2897 : 2008. Badan Standarisasi Nasional. 
[14] Todar, K. 2005. Staphylococcus. www.textbookofbacteriology.net.html. Accessed on 21 September 2016

[8] Sandar Nasional Indonesia, 2009. Batas Maksimum Cemaran Mikroba Dalam Pangan. SNI 7388: 2009. Badan Standarisasi Nasional.

[9] Wilshaw, GA, Cheasty, T., Smith, HR, 2000. Escherichia coli. In: Lund,BM, Baird Parker, TC, Gould, GW(Eds.), The Microbiological Safetyand Quality of Food II. Aspen Publishers Inc., Gaithersburg, Maryland, j.pp. 1136-1177. Accessed on 21 September 2016

[10] Baird Parker, TC, Gould, GW (Eds.), The Microbiological Safetyand Quality of Food II. Aspen Publishers Inc., Gaithersburg, Maryland, j.pp. 1136-1177. Accessed on 21 September 2016

[11] B. Koentoro, R.R.A. Maheswari dan H. Nuraeni. 2013. Mutu Fisik dan Mikrobiologi Daging Sapi Asal Rumah potong Hewan (RPH) Kota Pekanbaru. Jurnal Peternakan Vol 10. No. 1 Februari 2013. (1-8)

[12] Endang, S. 2009. Tinjauan Bahan Pangan Asal Hewan Yang Asuh Berdasarkan Aspek.

[13] Aiada Daw Mohamed, Ramadan Daw Mohamed, haow Mohamed madi, Sumayyah Ahmed abdullah, 2017. Microbiological quality of fresh and frozen ground meat, Alexandria city, Egypt. Saudi J. Pathol. Microbiol.; Vol-2, Iss-9 (Oct, 2017):286-290 